\title{
Computer simulation of energy use, greenhouse gas emissions, and costs for alternative methods of processing fluid milk ${ }^{1}$
}

\author{
P. M. Tomasula, ${ }^{* 2}$ N. Datta,† W. C. F. Yee, ${ }^{*}$ A. J. McAloon, $\ddagger$ D. W. Nutter,§ F. Sampedro,\# and L. M. Bonnaillie* \\ *Dairy and Functional Foods Research Unit, USDA, Agricultural Research Service, Eastern Regional Research Center, 600 E. Mermaid Lane, \\ Wyndmoor, PA 19038 \\ †Victoria University, College of Health and Bio-Medicine, Werribee Campus, PO Box 14428, Melbourne, Victoria 8001 Australia \\ †Engineering and Scale-up, Process and Economics Research Support Group, USDA, Agricultural Research Service, \\ Eastern Regional Research Center, 600 E. Mermaid Lane, Wyndmoor, PA 19038 \\ §University of Arkansas, Mechanical Engineering Department, Fayetteville 72701 \\ \#Center for Animal Health and Food Safety, College of Veterinary Medicine, University of Minnesota, St. Paul 55108
}

\section{ABSTRACT}

Computer simulation is a useful tool for benchmarking electrical and fuel energy consumption and water use in a fluid milk plant. In this study, a computer simulation model of the fluid milk process based on high temperature, short time (HTST) pasteurization was extended to include models for processes for shelfstable milk and extended shelf-life milk that may help prevent the loss or waste of milk that leads to increases in the greenhouse gas (GHG) emissions for fluid milk. The models were for UHT processing, crossflow microfiltration (MF) without HTST pasteurization, crossflow MF followed by HTST pasteurization (MF/HTST), crossflow MF/HTST with partial homogenization, and pulsed electric field (PEF) processing, and were incorporated into the existing model for the fluid milk process. Simulation trials were conducted assuming a production rate for the plants of 113.6 million liters of milk per year to produce only whole milk (3.25\%) and $40 \%$ cream. Results showed that GHG emissions in the form of process-related $\mathrm{CO}_{2}$ emissions, defined as $\mathrm{CO}_{2}$ equivalents (e) $/ \mathrm{kg}$ of raw milk processed (RMP), and specific energy consumptions (SEC) for electricity and natural gas use for the HTST process alone were 37.6 $\mathrm{g}$ of $\mathrm{CO}_{2} \mathrm{e} / \mathrm{kg}$ of RMP, $0.14 \mathrm{MJ} / \mathrm{kg}$ of RMP, and 0.13 $\mathrm{MJ} / \mathrm{kg}$ of RMP, respectively. Emissions of $\mathrm{CO}_{2}$ and SEC for electricity and natural gas use were highest for the PEF process, with values of $99.1 \mathrm{~g}$ of $\mathrm{CO}_{2} \mathrm{e} / \mathrm{kg}$ of $\mathrm{RMP}, 0.44 \mathrm{MJ} / \mathrm{kg}$ of RMP, and $0.10 \mathrm{MJ} / \mathrm{kg}$ of RMP, respectively, and lowest for the UHT process at $31.4 \mathrm{~g}$ of $\mathrm{CO}_{2} \mathrm{e} / \mathrm{kg}$ of RMP, $0.10 \mathrm{MJ} / \mathrm{kg}$ of RMP, and $0.17 \mathrm{MJ} /$

\footnotetext{
Received September 30, 2013.

Accepted March 11, 2014.

${ }^{1}$ Mention of trade names or commercial products in this publication is solely for the purpose of providing specific information and does not imply recommendation or endorsement by the US Department of Agriculture. The USDA is an equal opportunity provider and employer.

${ }^{2}$ Corresponding author: peggy.tomasula@ars.usda.gov
}

$\mathrm{kg}$ of RMP. Estimated unit production costs associated with the various processes were lowest for the HTST process and MF/HTST with partial homogenization at $\$ 0.507 / \mathrm{L}$ and highest for the UHT process at $\$ 0.60 / \mathrm{L}$. The increase in shelf life associated with the UHT and MF processes may eliminate some of the supply chain product and consumer losses and waste of milk and compensate for the small increases in GHG emissions or total SEC noted for these processes compared with HTST pasteurization alone. The water use calculated for the HTST and PEF processes were both $0.245 \mathrm{~kg}$ of water $/ \mathrm{kg}$ of RMP. The highest water use was associated with the MF/HTST process, which required 0.333 $\mathrm{kg}$ of water $/ \mathrm{kg}$ of RMP, with the additional water required for membrane cleaning. The simulation model is a benchmarking framework for current plant operations and a tool for evaluating the costs of process upgrades and new technologies that improve energy efficiency and water savings.

Key words: greenhouse gas, energy use, water use, nonthermal milk processing

\section{INTRODUCTION}

In the United States, agricultural emissions attributed to the dairy sector are approximately $1.9 \%$ of total US greenhouse gas (GHG) emissions (Thoma et al., 2013). On-farm activities contribute the bulk of GHG emissions, which include $\mathrm{CH}_{4}$ and $\mathrm{N}_{2} \mathrm{O}$ emissions and, to a lesser extent, $\mathrm{CO}_{2}$ emissions. Off-farm activities contribute the remaining $28 \%$ of GHG emissions and are mainly energy-related $\mathrm{CO}_{2}$ emissions because of fossil fuel use. Off-farm activities include transportation of milk from the farm to the processing plant; milk processing, packaging, and plant cold storage; transportation to distributors and retailers; and refrigeration of milk in the home.

At the milk processing plant, $\mathrm{CO}_{2}$ emissions arise mainly from natural gas, although other fossil fuels may be used in some cases (NRCan, 2001), and electricity. 
Energy information data for fluid milk plants throughout the United States and other dairying countries have been provided by Xu and Flapper (2009) so that individual plants may benchmark their performance. This information was provided in terms of the specific energy consumption (SEC), which is the energy use of the entire plant divided by the total milk production of the plant, with values ranging from 0.2 to $6.0 \mathrm{MJ} / \mathrm{kg}$ of fluid milk product. The low end of the range indicates an energy-efficient plant. To help processors lower their energy use, tools are needed so that processors may benchmark their processes and identify the unit operations or interactions of unit operations in their plants that consume the greatest amounts of energy and contribute the most to GHG emissions. Tools are also needed to help processors make changes and observe their effects in their plants, such as the implementation of new technologies on energy use and costs, without conducting costly experiments.

In a previous study (Tomasula et al., 2013), we developed a model of the fluid milk process for use in process design software as a tool for improving the energy efficiency of processing plants and to lower GHG emissions, or the carbon footprint, of milk processing plants. The model links modules that represent the unit operations composing the fluid milk process, allowing calculation of the mass and energy balances at each unit operation and the economics of the process from literature and industry information. The model is fully customizable and allows processors to enter their own operating parameters and cost data. The model was validated for several processing scenarios in fluid milk production.

A recent life cycle assessment conducted by the US dairy industry reported that the sum of GHG emissions from off-farm and on-farm activities was $2.05 \mathrm{~kg}$ of $\mathrm{CO}_{2}$ equivalents $\left(\mathbf{C O}_{2} \mathbf{e}\right) / \mathrm{kg}$ of fluid milk consumed $(90 \%$ confidence limits: 1.77-2.4; Thoma et al., 2013). Contributing to these emissions was an assumed amount of up to $12 \%$ of milk that is lost or wasted at the retail level and of up to $20 \%$ of milk that is lost at the point of consumption. One way to reduce loss and waste and thus energy use and GHG emissions further through the supply chain may be through production of fluid milk with extended shelf-life (ESL) or shelf-stable milk.

Extended shelf-life milk has a shelf life that ranges from a few days to up to $45 \mathrm{~d}$ under refrigeration (Elwell and Barbano, 2006; Goff and Griffiths, 2006; Rysstad and Kolstad, 2006) if made with good quality raw milk, sterile filling systems, and careful handling during storage and distribution to maintain temperature below $6^{\circ} \mathrm{C}$. Extended shelf-life milk is known as ultrapasteurized (UP) milk if heated to a temperature $\geq 137.8^{\circ} \mathrm{C}$ for $\geq 2 \mathrm{~s}$ and packaged nonaseptically. It may also result from processes that heat milk to about $127^{\circ} \mathrm{C}$ with a hold time of $5 \mathrm{~s}$ (Goff and Griffiths, 2006) or that microfilter milk to remove somatic cells, bacteria, and spores and then heat-treat it using HTST pasteurization at about $74^{\circ} \mathrm{C}$ (Elwell and Barbano, 2006; Hoffman et al., 2006). Shelf-stable milk is UHT milk that has been heat treated at a temperature $\geq 137.8^{\circ} \mathrm{C}$ for $\geq 2 \mathrm{~s}$ and packaged aseptically (Datta et al., 2002). It uses a commercial sterilization process lethal to microorganisms and spores and has a shelf life of 6 mo.

The fluid milk process may be considered to extend from milk reception and storage of raw milk in silos to cold storage; it includes milk standardization (6.7\%), homogenization $(9.2 \%)$, HTST pasteurization (16.1\%), filling and packaging (23.7\%), cleaning-in-place (CIP; $41.3 \%)$, and waste-water treatment $(0.8 \%)$ operations. The values in parentheses are the percentage energy use associated with the operations on a cold-storage-free basis determined by computer simulation (Tomasula et al., 2013). However, cold storage of milk can contribute an estimated 5 to $60 \%$ of GHG emissions depending on whether cold storage is considered only as a part of the processing plant or considered to extend to a distribution center and retail outlets. Milk packaging, homogenization, standardization, and cold storage utilize electrical energy whereas milk pasteurization and CIP require steam from fossil fuel burning. It is apparent from the list above that several of the unit operations could be targeted for reductions in energy use. For instance, process simulation may be used to examine the energy use and GHG emissions of other milk preservation technologies, such as UHT processing and microfiltration (MF), and alternative technologies, such as pulsed electric fields (PEF; Toepfl et al., 2006). Pulsed electric field processing is a nonthermal technology that has the potential to pasteurize milk by exposure to short, high-voltage electric pulses. These processes may demonstrate savings in energy, GHG emissions, and water use compared with HTST pasteurization (Tomasula and Nutter, 2011; Tomasula et al., 2013) but it would be difficult to investigate the processes in a laboratory or pilot-plant setting.

The goal of this study was to develop models for alternative pasteurization methods for milk such as UHT processing, crossflow MF, and PEF processing; incorporate them as modules into the fluid milk simulator; and use them to calculate the energy use, GHG emissions, water use and economics of the processes compared with HTST pasteurization.

\section{MATERIALS AND METHODS}

\section{Model Development}

The fluid milk process model (FMPM; Tomasula et al., 2013) incorporates HTST pasteurization of milk 
with equipment specifications and cost data, using the commercial software package SuperPro Designer (http://www.intelligen.com, Version 9.0 Build 8; Intelligem Inc., Scotch Plains, NJ). The flow sheet diagram of the fluid milk process from Tomasula et al. (2013) is shown in Figure 1. It is used as the template for the inclusion and development of models for UHT processing of milk, crossflow MF with or without HTST pasteurization, crossflow MF with partial homogenization followed by HTST pasteurization, and PEF processing.

The simulations of the various plants assumed a medium-sized plant processing 113.6 million L/yr (30.0 million gal/yr), or $27,300 \mathrm{~L} / \mathrm{h}$ of raw whole milk to produce $3.25 \%$ milk (whole milk) and $40 \%$ cream (cream with $40 \%$ fat content). No other products are assumed. The simulations extend from storage of raw milk in silos to cold storage of the packaged product temporarily on site, if applicable, for the particular model. The plants are assumed to operate continuously with milk processed for $260 \mathrm{~d} / \mathrm{yr}, 16 \mathrm{~h} / \mathrm{d}$, with $8 \mathrm{~h}$ dedicated to cleaning in accord with the previous study (Tomasula et al., 2013). The separate models and processes are described below.

\section{Description of the Models}

Fluid Milk Process with HTST Pasteurization. This base case assumes the FMPM with the flow sheet given in Figure 1. Briefly, we assumed that raw milk was pumped from the milk silos to the balance tank and drawn to the first preheat regenerating heat exchanger (B-HX102). The milk was then deaerated and separated into skim milk and cream streams. The cream was processed into heavy cream. The milk was homogenized before entering the second preheat regenerating heat exchanger (B-HX103) and then assumed pasteurized (B-HX104) at $77^{\circ} \mathrm{C}$, followed by a hold time of $22 \mathrm{~s}$ (B-HTB121). The regeneration rates of the milk and cream pasteurizers were assumed as $94 \%$, in keeping with Tomasula et al. (2013). Cream was pasteurized at $90^{\circ} \mathrm{C}$ with a hold time of $15 \mathrm{~s}$. The milk was cooled by regenerative cooling and then packaged in highdensity polyethylene gallon jugs, blown on site. Cream was packaged in paper pint containers. Milk and cream were stored on site at $1.8^{\circ} \mathrm{C}$ for up to $1.5 \mathrm{~d}$ until shipped to a distribution center or retail stores.

Two values of energy consumption for onsite cold storage were used previously (Tomasula et al., 2013) to illustrate the difference in total energy use between a plant having cold storage with high energy consumption and one with low energy consumption. In this study, all plants were assumed to have energy efficient, onsite cold storage. A value of electricity index of $0.840 \mathrm{kWh} / \mathrm{m}^{2}$ per day (ASHRAE, 2007) for refrigerated warehouses was used to calculate energy use. Case washing was accomplished using ultrasonic washers that consumed $6,000 \mathrm{~L} / \mathrm{d}$ of water. All plants had a cold storage facility for milk and cream, with the exception of the UHT plant, which had cold storage for the cream only.

The CIP operations were assumed with each cleaning step modeled as one cycle per day. One skid was designated for the milk silos, tanks, and filling machines. A second was designated for the pasteurizers. For plants with MF, an additional CIP tank was added for cleaning the membranes. Wastewater from the ultrasonic case washers and CIP operations and the sludge from the separator were sent to an onsite aeration tank for the bio-oxidation of the organic material in the stream.

Fluid Milk Process with UHT Processing. The UHT processing of milk is conducted at a minimum temperature-time combination of $\geq 137.8^{\circ} \mathrm{C}$ for $\geq 2 \mathrm{~s}$ but is frequently conducted at higher temperatures and holding times. Either direct or indirect heating (Burton, 1988; Datta et al., 2002) is used. In direct heating, superheated steam is mixed directly with milk. Indirect heating is accomplished using tubular heat exchangers or plate heat exchangers for heating of milk. Both methods are in use throughout the world, with indirect heating being more common. The indirect heating method is assumed in this study.

The process model for UHT processing (Figure 2) builds upon the base case FMPM of Figure 1, with removal of the HTST pasteurizers from the model and replacement with tubular heat exchangers according to the generic process flow sheet found in Burton (1988). The packaging equipment of the base FMPM was replaced with an aseptic packaging line, such as the Tetra Pak A3 Flex Filling Machine. The energy use information for entry into the simulator was obtained from P. Perry (Tetra Pak Oceania, New South Wales, Australia; personal communication) and pricing information was obtained from vendors. The equipment unit ID information for the UHT process of Figure 2 is given in Table 1.

This process was assumed to operate as described in Burton (1988). Focusing only on the heating stage, after the milk is preheated (B-HX102), separated (CCS124), and homogenized (D-HG127) to produce $3.25 \%$ whole milk, it enters a second preheater (B-HX103) at approximately $75^{\circ} \mathrm{C}$ and leaves at approximately $95^{\circ} \mathrm{C}$. The stream then enters a holding tube (B-HT124) for about $1 \mathrm{~min}$ and then to the final heating stage (B-HX104), which heats the stream to $137.8^{\circ} \mathrm{C}$. The stream was held for $4 \mathrm{~s}$ in B-HT121 and then cooled in B-HX106. The percentage regeneration of this process is $91 \%$.

The milk was stored in an aseptic vessel before aseptic filling and packaging at F-FL203. Cream was 


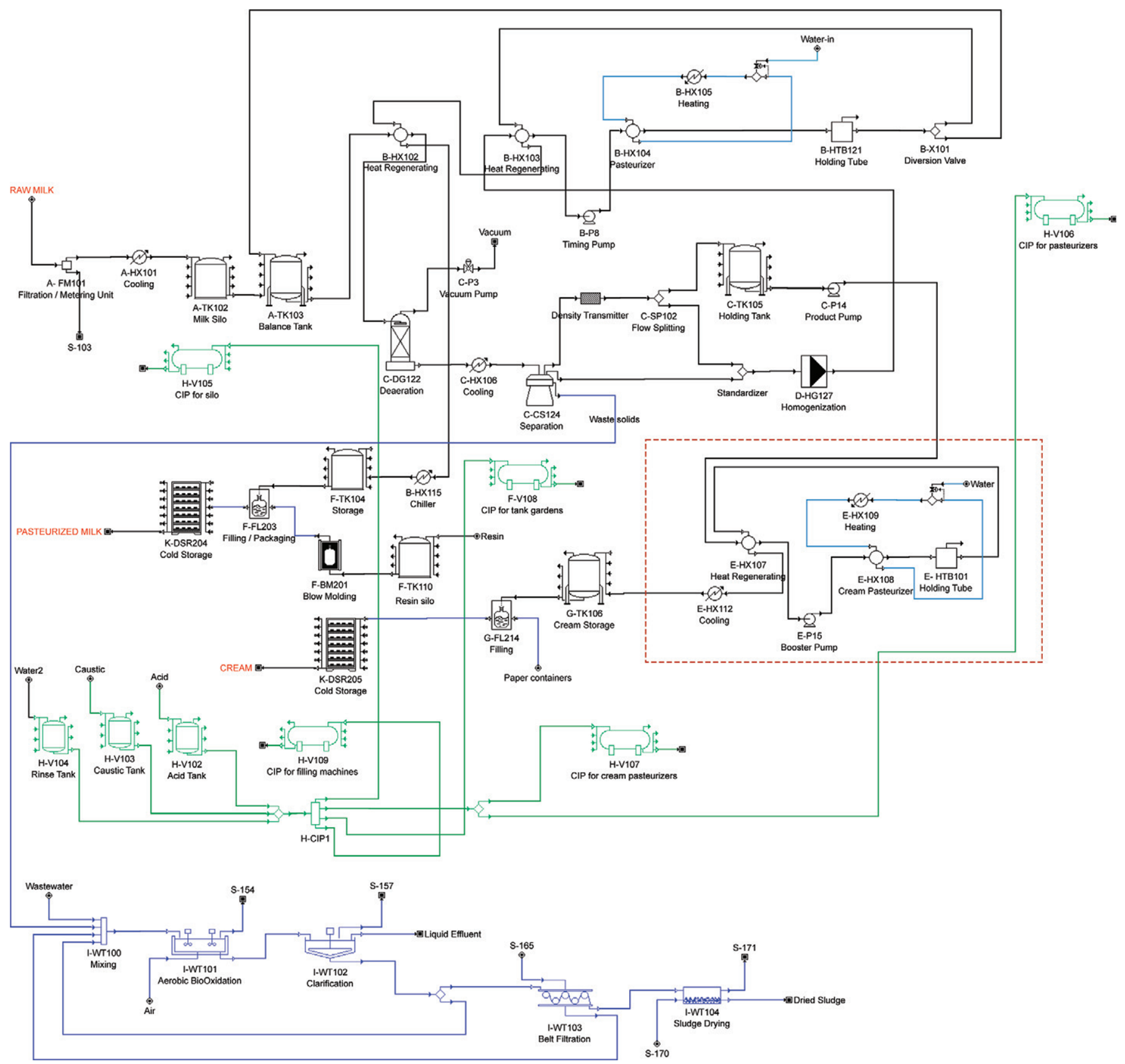

Figure 1. Process flow sheet of the fluid milk model (HTST pasteurization) with full homogenization. CIP = cleaning in place. Color version available in online PDF.

packaged in paper pint containers and stored on site. The CIP operations were assumed similar to those for the FMPM (Figure 1) but additional water was used in cleaning. Wastewater was handled as described for the FMPM.

Crossflow MF Without Pasteurization. Microfiltered whole milk is sold as an ESL raw milk in France (Saboya and Maubois, 2000; Gésan-Guiziou, 2010). The cream stream is heated to $95^{\circ} \mathrm{C}$ for $20 \mathrm{~s}$. To simulate this process, the MF process was installed as part of the FMPM but the HTST section was removed (Figure 3). A regenerative heat exchanger (B-HX102) was followed by a hot water-heated heat exchanger (B-HX104) to heat milk to $55^{\circ} \mathrm{C}$ before MF (Gésan-Guiziou, 2010). For the purposes of comparison to other cases in this study, we assumed that the cream was heated to $90^{\circ} \mathrm{C}$ 


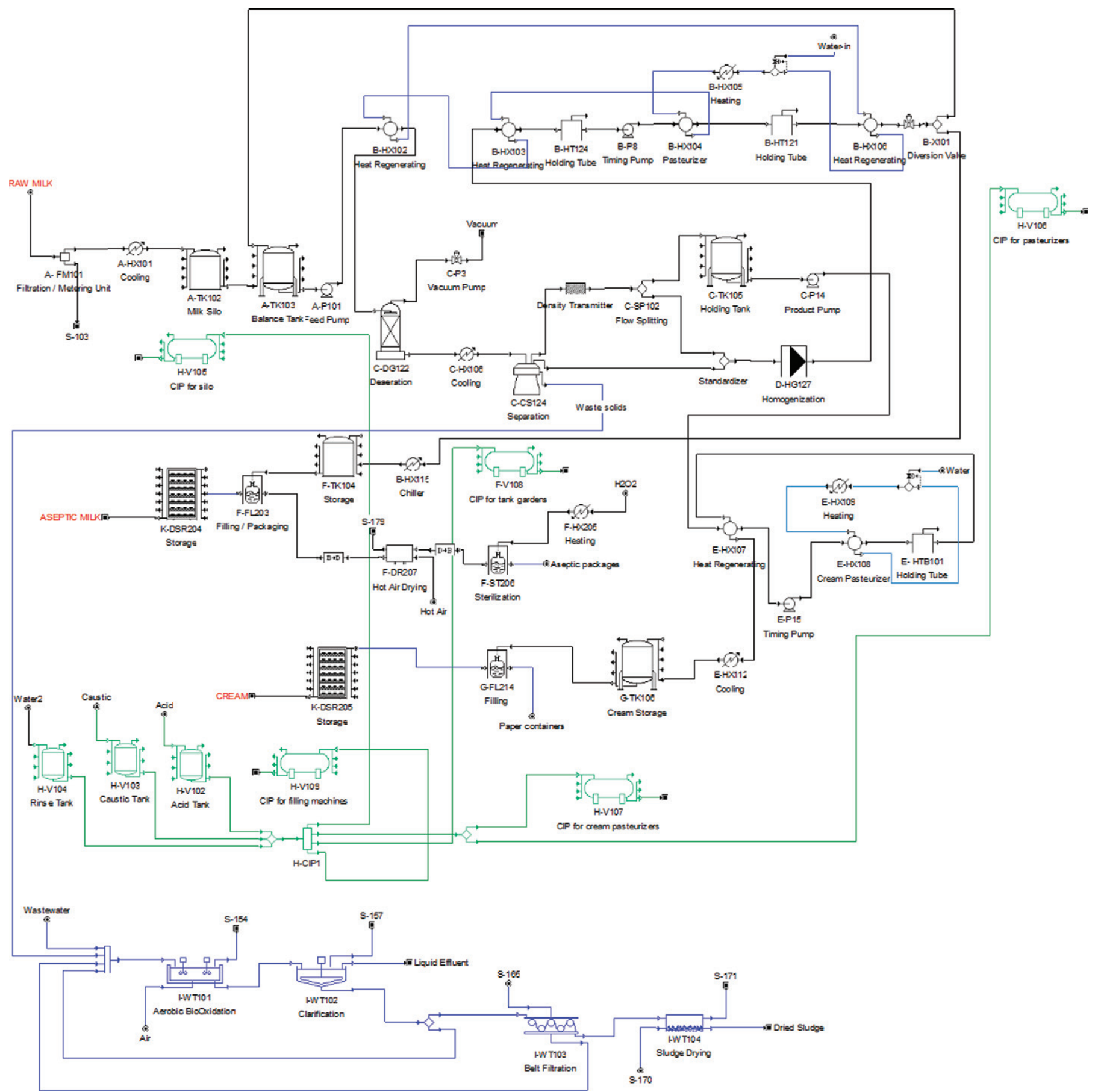

Figure 2. Process flow sheet for the UHT process with aseptic packaging. Unit identification is given in Table 1 . CIP $=$ cleaning in place. Color version available in online PDF.

and held for $15 \mathrm{~s}$ and then mixed with the permeate. Crossflow MF was modeled as 2 MF processing modules in series (Figure 3). Each of the modules consisted of housings containing 1.4- $\mu \mathrm{m}$ membranes. The first module (MF-101) was fed skim milk at $55^{\circ} \mathrm{C}$ with the retentate fed to a second module (MF-102). The permeate flux was set to $550 \mathrm{~L} / \mathrm{m}^{2} \mathrm{~h}$, a flow parameter commonly used in milk MF. The volume concentration ratio (VCR) is defined as follows:

$$
\mathrm{VCR}=\mathrm{V}_{\mathrm{F}} / \mathrm{V}_{\mathrm{R}}=\left(\mathrm{F}_{\mathrm{P}}+\mathrm{F}_{\mathrm{R}}\right) / \mathrm{F}_{\mathrm{R}}
$$

where $V_{F}$ is the volume of feed, $V_{R}$ is the volume of retentate, $F_{P}$ is the flow rate of the permeate, and $F_{R}$ 
Table 1. Overview of unit operations shown in Figures 2 through 6 for UHT processing, crossflow microfiltration (MF), and pulsed electric field (PEF) processing of $113,600,000 \mathrm{~L} / \mathrm{yr}$ of raw milk to produce whole milk and cream

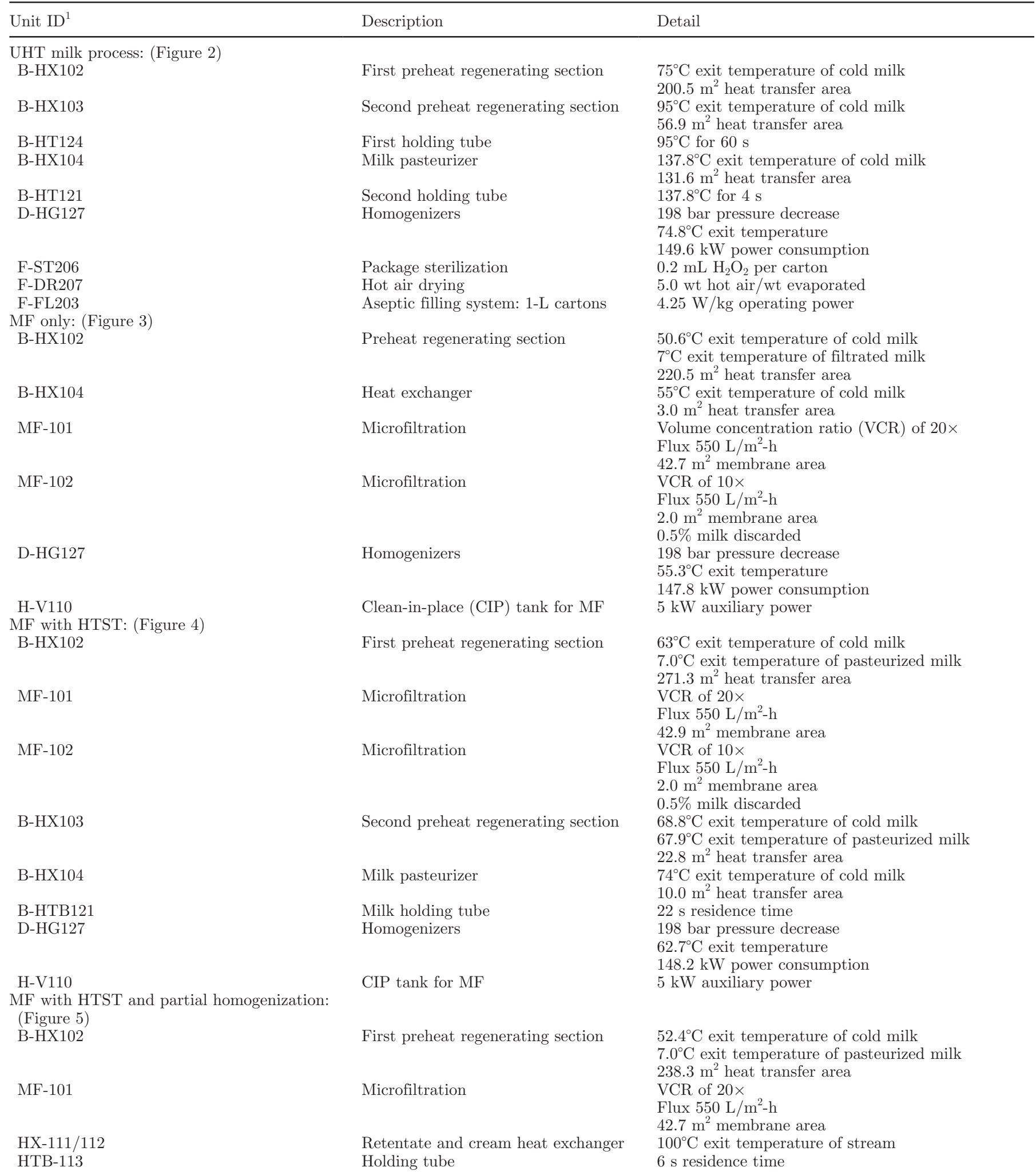


Table 1 (Continued). Overview of unit operations shown in Figures 2 through 6 for UHT processing, crossflow microfiltration (MF), and pulsed electric field (PEF) processing of 113,600,000 L/yr of raw milk to produce whole milk and cream

\begin{tabular}{lll}
\hline Unit ID $^{1}$ & Description & Detail \\
\hline B-HX103 & Second preheat regenerating section & $68.2^{\circ} \mathrm{C}$ exit temperature of cold milk \\
& & $56.8^{\circ} \mathrm{C}$ exit temperature of pasteurized milk ${ }^{2}$ \\
B-HX104 & Milk pasteurizer & $57.7 \mathrm{~m}^{2}$ heat transfer area \\
& & $74^{\circ} \mathrm{C}$ exit temperature of cold milk \\
B-HTB121 & Milk holding tube & $11.2 \mathrm{~m}^{2}$ heat transfer area \\
D-HG127 & Homogenizers & $22 \mathrm{~s}^{2}$ esidence time \\
& & 198 bar pressure decrease \\
H-V110 & CIP tank for MF & $83.5^{\circ} \mathrm{C}$ exit temperature \\
PEF milk process: (Figure 6) & & $19.4 \mathrm{~kW}$ power consumption \\
B-HX102 & Preheat regenerating section & $5 \mathrm{~kW}$ auxiliary power \\
& & $55^{\circ} \mathrm{C}$ exit temperature of cold milk \\
PEF-1-2-3 & & $17.4^{\circ} \mathrm{C}$ exit temperature of processed milk \\
HX-201/202 & & $70.3 \mathrm{~m}{ }^{2}$ heat transfer area \\
D-HG127 & Pulsed electric field system & $65.4^{\circ} \mathrm{C}$ exit temperature \\
& Internal cooler & $510 \mathrm{~kW}$ power consumption \\
H-V110 & Homogenizers & $50^{\circ} \mathrm{C}$ exit temperature \\
\hline
\end{tabular}

${ }^{1}$ The first letter of the unit ID identifies the location of the unit in the respective figure.

${ }^{2} \mathrm{HX}-201$ follows PEF-1 and HX-202 follows PEF-2.

is the flow rate of the retentate. The VCR for the first module was assumed to have a value of 20 , representing a $20 \times$ concentration of milk; the VCR for the second module was 10, for an overall VCR for the MF process of 200 . The retentate, which is about $0.5 \%$ of the total feed stream, was assumed processed as a waste stream, because the stream was $200 \times$ concentrated in bacteria.

Although the ESL raw milk is filled aseptically and then refrigerated at $<6^{\circ} \mathrm{C}$, it was assumed here that the milk was filled, packaged, and stored similarly to the FMPM. An additional CIP tank (H-V110) was installed for cleaning the MF modules (Table 1).

Crossflow MF Followed by HTST Pasteurization. In recent years, many processing plants have been exceeding the minimum pasteurization conditions of $72^{\circ} \mathrm{C}$ for $15 \mathrm{~s}$ (FDA, 2011) in an effort to extend milk shelf life. Processors observed (Ranieri et al., 2009), however, that the increased pasteurization temperatures resulted in an increase in bacterial growth and a shortened milk shelf life. Milk pasteurized at the higher temperatures seemed to promote the growth of Paenibacillus spp., a psychrotolerant endospore-forming bacteria that is present in very low levels in raw milk to levels exceeding the Pasteurized Milk Ordinance (2011 revision) limit of 20,000 cfu/mL (FDA, 2011). Ranieri et al. (2009) recommended the use of MF (Elwell and Barbano, 2006; Hoffman et al., 2006; Tomasula et al., 2011) for removal of bacteria and spores from raw milk.

The flow sheet for the MF process followed by HTST pasteurization (MF/HTST) is shown in Figure 4 and is based on the FMPM. Milk was heated to $63^{\circ} \mathrm{C}$ in the first preheat regenerating section (B-HX102) but cooled to $55^{\circ} \mathrm{C}$ following separation and before feeding to the MF section. The other significant operating conditions are given in Table 1. Two MF modules in series were used as described for the raw milk crossflow MF process without pasteurization. Permeates from both MF modules were combined with the cream and homogenized. This whole milk stream was then pasteurized at $74^{\circ} \mathrm{C}$, a lower temperature than that of $77^{\circ} \mathrm{C}$ used in the FMPM, but was held for $22 \mathrm{~s}$, similar to the FMPM. Regeneration efficiency was $93 \%$.

Crossflow MF with Partial Homogenization and Pasteurization. A process concept for production of ESL milk, defined by the manufacturer (GEA Inc., 2013) as milk with a shelf life of at least $21 \mathrm{~d}$ when stored at $8^{\circ} \mathrm{C}$, combines HTST pasteurization with MF and uses partial homogenization to blend the retentate stream with a portion of the cream stream before adding it to the permeate. The process flow sheet is shown in Figure 5, with additional data given in Table 1. Compared with the previous MF concepts of Figures 3 and 4, which used $2 \mathrm{MF}$ units in series, a single MF module with VCR of 20 was used. The retentate stream was approximately $5 \%$ of the feed milk flow rate and was $20 \times$ concentrated in bacteria and used in the final product. After the retentate and cream streams were blended, they were treated at $100^{\circ} \mathrm{C}$ and held for $6 \mathrm{~s}$ before adding them to the permeate stream. The whole milk stream was then sent to the second preheating 


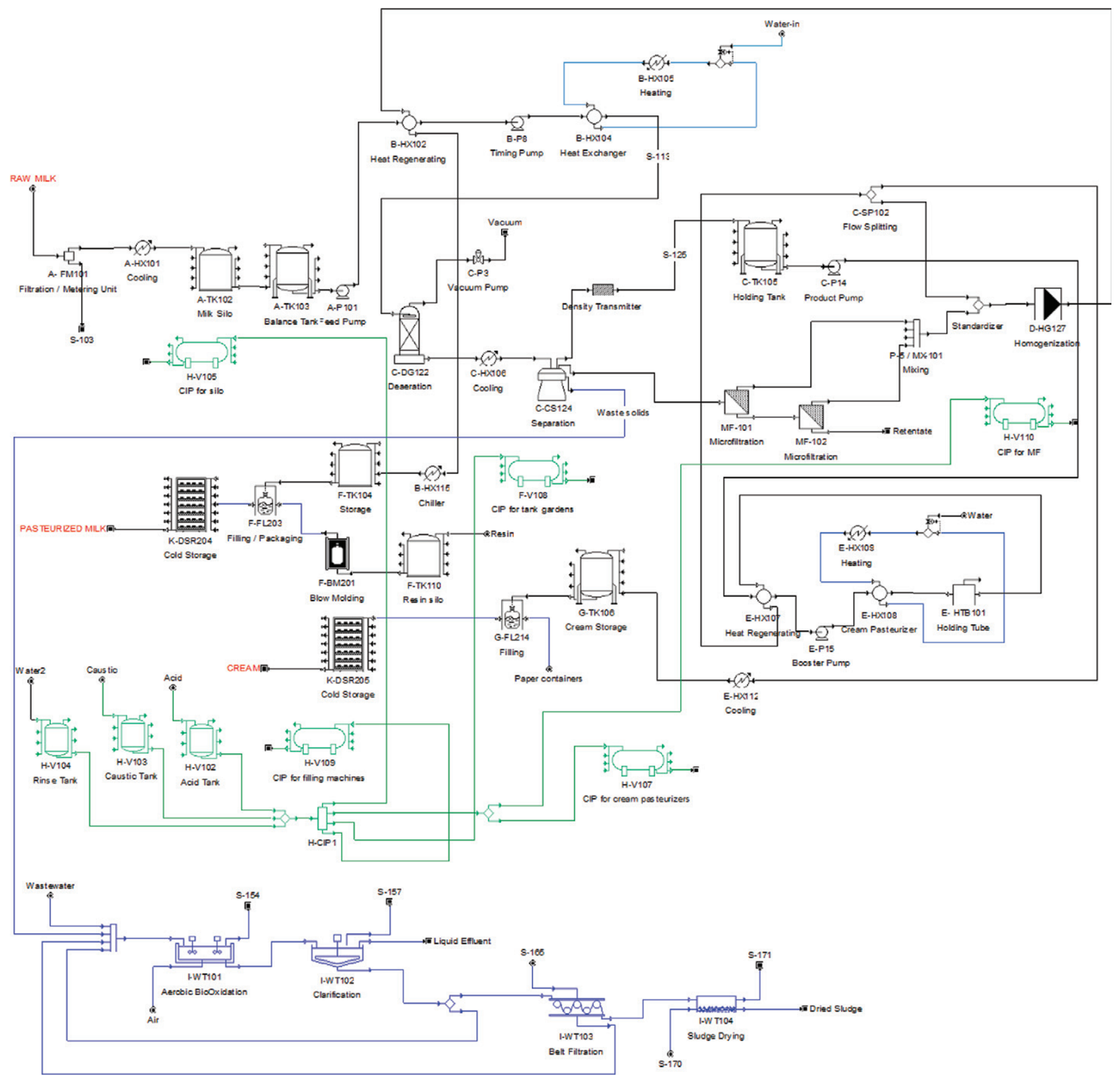

Figure 3. Crossflow microfiltration (MF) without HTST pasteurization with a volume concentration ratio (VCR) of 200. Unit identification is given in Table 1 . CIP = cleaning in place. Color version available in online PDF.

stage of the HTST pasteurizer and pasteurized. Regeneration efficiency was $92 \%$, with the rest of the process similar to that of the other MF models.

PEF Pasteurization. A process concept for production of pasteurized whole milk using PEF processing has been proposed for pasteurization of orange juice and is adapted here for pasteurization of milk (Sampedro et al., 2013), with modifications for a continuous fluid milk process. Two modes of action for elimination of bacteria in a fluid by PEF processing have been proposed: (1) structural and functional changes in the cell membrane leading to death (Mañas and Pagán, 2005) and (2) electroporation (Sobrino-Lopez and Martin-Belloso, 2010). The process flow sheet for a milk process is shown in Figure 6 and is similar in layout to the plant for crossflow MF of milk without HTST 


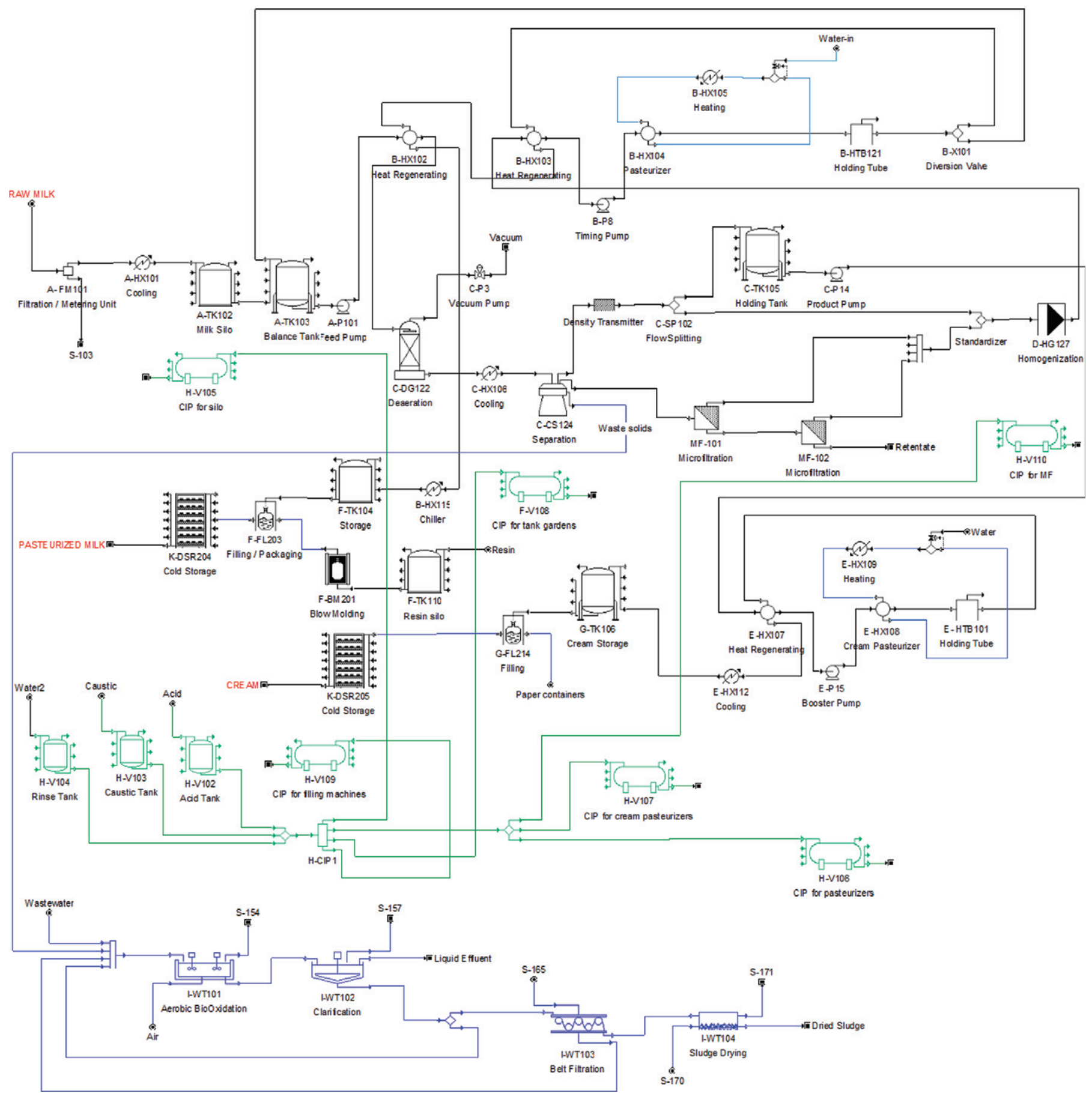

Figure 4. Process flow sheet of microfiltration (MF) process before HTST pasteurization at $74^{\circ} \mathrm{C}$ with a volume concentration ratio (VCR) of 200. Unit identification is given in Table 1 . CIP = cleaning in place. Color version available in online PDF.

pasteurization (Figure 3). After preheating in a regenerator (B-HX102) to $55^{\circ} \mathrm{C}$, the milk is separated and skim milk enters the PEF system at $50^{\circ} \mathrm{C}$. The system is modeled as $3 \mathrm{PEF}$ units in parallel, with each unit handling up to $10,000 \mathrm{~L} / \mathrm{h}$ of milk. The icon on the flow sheet represents the 3 units. Each PEF unit consists of 3 subunits composed of 2 treatment chambers each connected in series (6 processing chambers) in total. The treatment time in each unit may range from 50 to $150 \mu \mathrm{s}$ for electric field strengths of 30 to $40 \mathrm{kV} / \mathrm{cm}$. A heat exchanger is part of each unit and is after the first and second pairs to remove ohmic heat, which is 


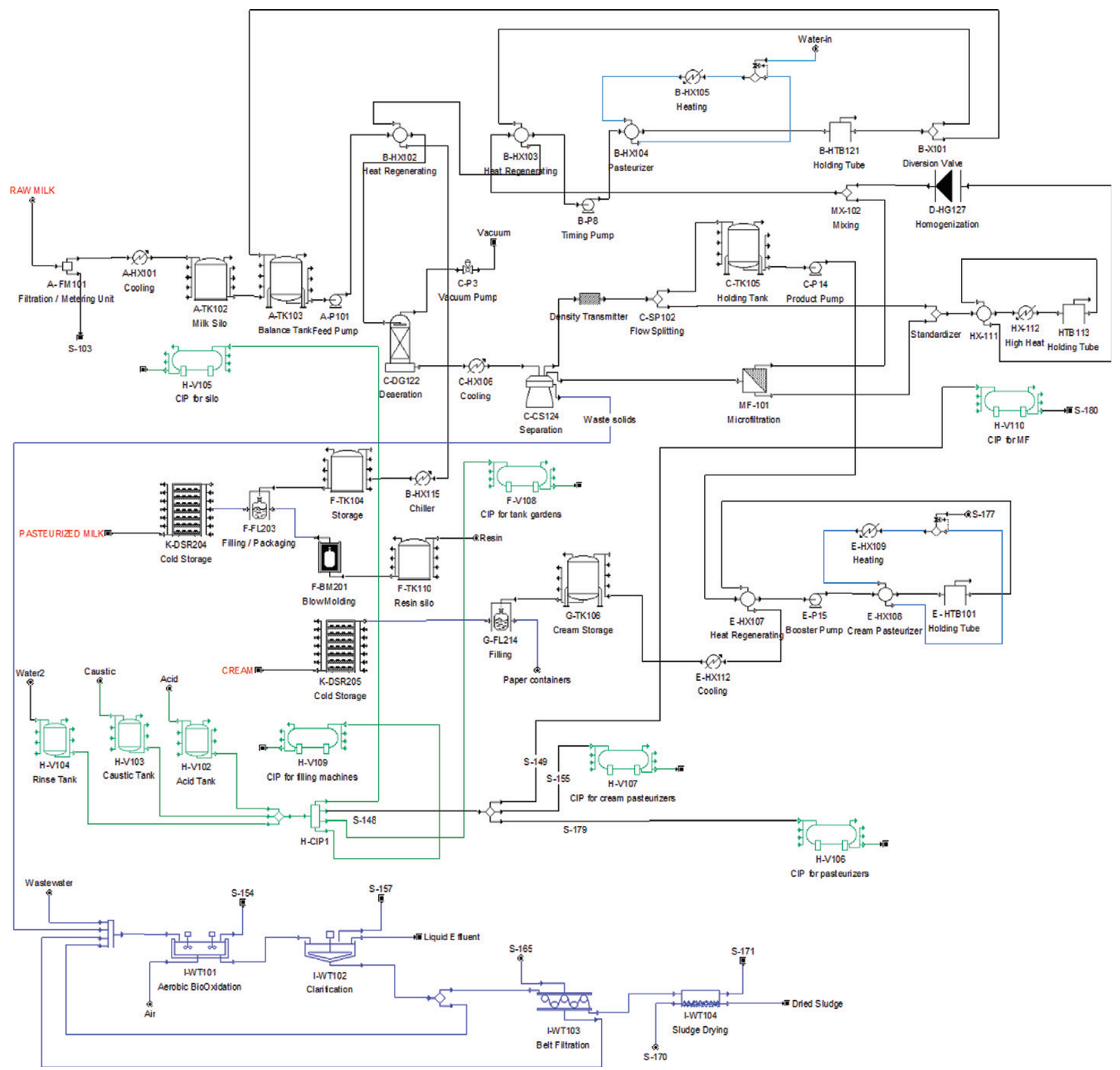

Figure 5. Process flow sheet of the GEA microfiltration (MF) process (GEA Inc., 2013) with partial homogenization of the cream and retentate streams and a volume concentration ratio $(\mathrm{VCR})$ of 20 . Unit identification is given in Table 1 . CIP $=$ cleaning in place. Color version available in online PDF.

about $15^{\circ} \mathrm{C}$ in each chamber. After leaving the last pair of chambers of the 3 PEF units, the hot milk is routed through the hot side of the heat recovery exchanger, where it is cooled and then passed through a final cooling heat exchanger to reduce its temperature to $1.7^{\circ} \mathrm{C}$ before packaging and cold storage. An additional CIP tank H-V110 is also included.

\section{Extracting Data from a Simulation Trial}

The methodologies for running a simulation using SuperPro Designer and for obtaining data from the itemized cost report were described previously (Tomasula et al., 2013). The simulator calculates the energy used for each of the unit operations. These numbers are 


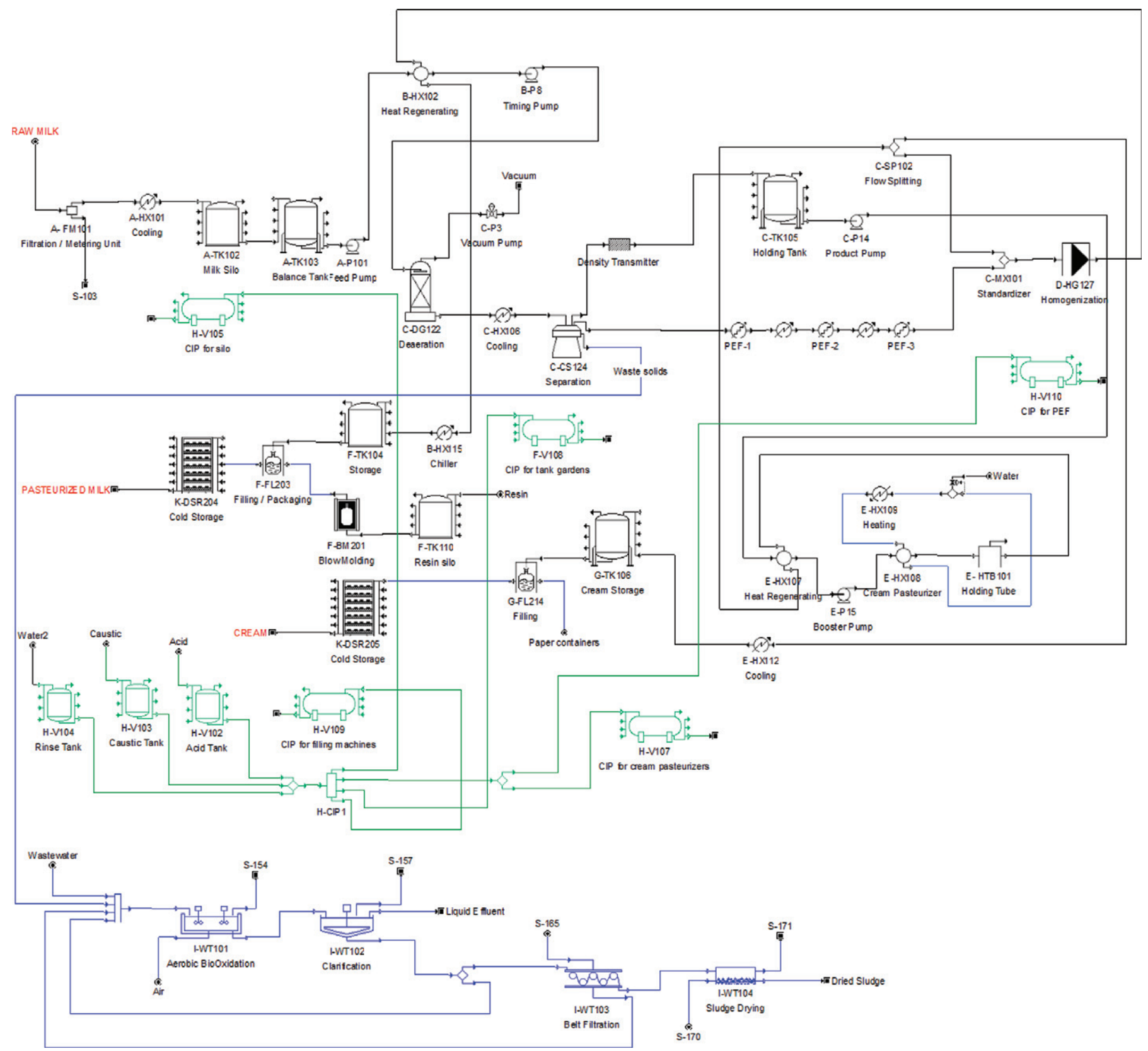

Figure 6. Process flow sheet of the pulsed electric field (PEF) process. Unit identification is given in Table 1. CIP $=$ cleaning in place. Color version available in online PDF.

referred to as bare numbers because they do not take into account the energy source, which could be from electricity, cooling water, chilled water, or steam. An Excel spreadsheet (Microsoft Corp., Redmond, WA) was then used to extract the energy data for electricity, cooling water, chilled water, and steam, which was then converted by applying allowances. Allowances are used in cost estimating to cover the costs of known but not fully defined processes. An allowance of up to $25 \%$ as described in Peters et al. (2003) was added to the bare numbers from the unit operations to account for the nonprocess utility requirements and efficiency of the electrical processes as described previously (Tomasula et al., 2013). A $20 \%$ allowance was added to the bare numbers for converting the energy from natural gas energy to steam energy.

Greenhouse gas emissions for the unit operations were calculated from the energy data shown in Table 2 using the conversion factors found in Deru and Torcellini (2007). The source emission factor for conversion of 
Table 2. Energy and specific energy consumption (SEC) associated with electricity and natural gas use to process 113,600,000 L/yr raw milk using the fluid milk process model (FMPM), UHT processing, crossflow microfiltration (MF) with no pasteurization and a volume concentration ratio (VCR) of 200, MF/HTST with a VCR of 200, MF/HTST with a VCR of 20 , or pulsed electric field processing (PEF)

\begin{tabular}{|c|c|c|c|c|c|c|}
\hline Section & $\begin{array}{c}\text { FMPM with HTST } \\
\text { at } 77^{\circ} \mathrm{C}, \\
\text { MJ }(\%)\end{array}$ & $\begin{array}{l}\text { UHT process, } \\
\text { MJ (\%) }\end{array}$ & $\begin{array}{c}\text { Crossflow } \\
\text { MF, no HTST, } \\
(\text { VCR }=200) \\
\text { MJ }(\%)\end{array}$ & $\begin{array}{c}\text { Crossflow } \\
\mathrm{MF} / \mathrm{HTST} \text { at } 74^{\circ} \mathrm{C} \\
(\mathrm{VCR}=200) \\
\mathrm{MJ}(\%)\end{array}$ & $\begin{array}{c}\text { Crossflow }^{1} \\
\text { MF } / \text { HTST at } 74^{\circ} \mathrm{C} \\
(\mathrm{VCR}=20) \\
\text { MJ }(\%)\end{array}$ & $\begin{array}{c}\text { PEF, } \\
\text { MJ (\%) }\end{array}$ \\
\hline Raw milk & $\begin{array}{r}248,460 \\
(0.8)\end{array}$ & $\begin{array}{r}248,460 \\
(0.8)\end{array}$ & $\begin{array}{r}248,460 \\
(0.7)\end{array}$ & $\begin{array}{r}248,460 \\
(0.7)\end{array}$ & $\begin{array}{r}248,460 \\
(0.7)\end{array}$ & $\begin{array}{r}248,460 \\
(0.4)\end{array}$ \\
\hline Microfiltration & - & - & $\begin{array}{r}1,675,390 \\
(5.0)\end{array}$ & $\begin{array}{r}1,680,350 \\
(4.5)\end{array}$ & $\begin{array}{r}3,752,400 \\
(10.1)\end{array}$ & - \\
\hline Pulsed electric fields & - & - & - & - & - & $\begin{array}{r}31,455,520 \\
(51.7)\end{array}$ \\
\hline Pasteurization & $\begin{array}{r}4,867,250 \\
(16.1)\end{array}$ & $\begin{array}{r}11,625,220 \\
(38.0)\end{array}$ & $\begin{array}{r}4,539,070 \\
(13.7)\end{array}$ & $\begin{array}{r}5,045,740 \\
(13.5)\end{array}$ & $\begin{array}{r}5,507,860 \\
(14.8)\end{array}$ & $\begin{array}{r}3,938,040 \\
(6.5)\end{array}$ \\
\hline Homogenization & $\begin{array}{r}2,789,160 \\
(9.2)\end{array}$ & $\begin{array}{r}2,800,660 \\
(9.2)\end{array}$ & $\begin{array}{r}2,769,890 \\
(8.7)\end{array}$ & $\begin{array}{r}2,774,180 \\
(7.4)\end{array}$ & $\begin{array}{r}363,530 \\
(1.0)\end{array}$ & $\begin{array}{r}2,795,510 \\
(4.6)\end{array}$ \\
\hline Standardization & $\begin{array}{r}2,026,040 \\
(6.7)\end{array}$ & $\begin{array}{r}2,026,060 \\
(6.6)\end{array}$ & $\begin{array}{r}2,023,720 \\
(6.1)\end{array}$ & $\begin{array}{r}2,026,040 \\
(5.4)\end{array}$ & $\begin{array}{r}2,023,490 \\
(5.4)\end{array}$ & $\begin{array}{r}2,025,470 \\
(3.3)\end{array}$ \\
\hline Milk packaging & $\begin{array}{r}7,216,800 \\
(23.9)\end{array}$ & $\begin{array}{r}2,381,730 \\
(7.8)\end{array}$ & $\begin{array}{r}7,180,630 \\
(21.6)\end{array}$ & $\begin{array}{r}7,180,670 \\
(19.3)\end{array}$ & $\begin{array}{r}7,216,710 \\
(19.4)\end{array}$ & $\begin{array}{r}7,216,730 \\
(11.9)\end{array}$ \\
\hline Cream pasteurization & $\begin{array}{r}222,660 \\
(0.7)\end{array}$ & $\begin{array}{r}255,100 \\
(0.8)\end{array}$ & $\begin{array}{r}394,750 \\
(1.2)\end{array}$ & $\begin{array}{r}223,630 \\
(0.6)\end{array}$ & $\begin{array}{r}188,610 \\
(0.5)\end{array}$ & $\begin{array}{r}390,750 \\
(0.6)\end{array}$ \\
\hline Cream packaging & $\begin{array}{r}199,410 \\
(0.7)\end{array}$ & $\begin{array}{r}198,900 \\
(0.7)\end{array}$ & $\begin{array}{r}203,920 \\
(0.6)\end{array}$ & $\begin{array}{r}203,890 \\
(0.5)\end{array}$ & $\begin{array}{r}199,510 \\
(0.5)\end{array}$ & $\begin{array}{r}199,490 \\
(0.3)\end{array}$ \\
\hline Cold storage & $\begin{array}{r}1,825,050 \\
(6.0)\end{array}$ & - & $\begin{array}{r}1,825,050 \\
(5.5)\end{array}$ & $\begin{array}{r}1,825,050 \\
(4.9)\end{array}$ & $\begin{array}{r}1,825,050 \\
(4.9)\end{array}$ & $\begin{array}{r}1,825,050 \\
(3.0)\end{array}$ \\
\hline Cleaning-in-place & $\begin{array}{r}8,872,130 \\
(29.4)\end{array}$ & $\begin{array}{r}8,940,900 \\
(29.2)\end{array}$ & $\begin{array}{r}10,275,960 \\
(31.0)\end{array}$ & $\begin{array}{r}13,573,420 \\
(36.4)\end{array}$ & $\begin{array}{r}13,345,690 \\
(35.9)\end{array}$ & $\begin{array}{r}8,872,130 \\
(14.6)\end{array}$ \\
\hline Wastewater treatment & $\begin{array}{r}1,910,960 \\
(6.3)\end{array}$ & $\begin{array}{r}2,112,760 \\
(6.9)\end{array}$ & $\begin{array}{r}2,056,810 \\
(6.2)\end{array}$ & $\begin{array}{r}2,493,580 \\
(6.7)\end{array}$ & $\begin{array}{r}2,463,890 \\
(6.6)\end{array}$ & $\begin{array}{r}1,910,960 \\
(3.1)\end{array}$ \\
\hline Total energy & $30,178,030$ & $30,589,790$ & $33,193,650$ & $37,275,010$ & $37,135,200$ & $60,878,110$ \\
\hline $\mathrm{SEC}, \mathrm{MJ} / \mathrm{kg}$ of $\mathrm{RMP}^{2}$ & 0.267 & 0.270 & 0.293 & 0.329 & 0.328 & 0.538 \\
\hline SEC electrical, MJ $/ \mathrm{kg}$ of RMP & 0.14 & 0.10 & 0.16 & 0.16 & 0.13 & 0.44 \\
\hline SEC natural gas, MJ $/ \mathrm{kg}$ of RMP & 0.13 & 0.17 & 0.14 & 0.17 & 0.19 & 0.10 \\
\hline $\begin{array}{l}{ }^{1} \text { Partial homogenization. } \\
{ }^{2} \mathrm{RMP}=\text { raw milk processed. }\end{array}$ & & & & & & \\
\hline
\end{tabular}


electrical energy to $\mathrm{CO}_{2} \mathrm{e}$ was $0.758 \mathrm{~kg}$ of $\mathrm{CO}_{2} \mathrm{e} / \mathrm{kWh}$. The source emission factor that was used for conversion of natural gas energy to $\mathrm{CO}_{2} \mathrm{e}$ was $0.06312 \mathrm{~kg}$ of $\mathrm{CO}_{2} \mathrm{e}$ /MJ of natural gas.

The simulator provides cost data based on the economic conditions in 2013. The user may also enter their own data or data from vendors. Sanitary construction was assumed for all equipment costs. Further details are provided in Tomasula et al. (2013).

\section{RESULTS AND DISCUSSION}

\section{Energy Use of Simulated Plants}

Reduction of energy use throughout a plant or switching to lower global warming potential energy sources reduces GHG emissions. Dairy plants have already implemented best practices, which have reduced energy use by 5 to $30 \%$ (Doty and Turner, 2009; Tomasula and Nutter, 2011). However, few plants have examined reduction of energy use through implementation of alternative technologies that may reduce a particular type of energy use, either thermal or electrical, and the associated GHG emissions. These technologies may also lower water use and wastes generated throughout the dairy supply chain.

Simulation trials were conducted for the FMPM, UHT process, the various MF process configurations presented earlier, and the PEF process to demonstrate the use of the models in calculating the energy use of the different pasteurization scenarios, the effect on GHG emissions in the form of $\mathrm{CO}_{2} \mathrm{e}$ emissions, and the estimated cost of implementing the alternative process compared with the base FMPM. The energy use and percentage contribution to the total energy use of each of the unit operations in the processes, extending from milk reception and storage in silos to cold storage of the packaged product, are shown in Table 2. Specific energy consumption, which is useful for comparing the efficiencies across different fluid milk processing plants (Xu and Flapper, 2009), is also reported. The FMPM was verified by comparison to actual plant data and data from the literature (Tomasula et al., 2013).

For the base FMPM, energy use decreased in the order CIP $(29.4 \%)>$ milk packaging $(23.9 \%)>$ pasteurization (16.1\%), homogenization $(9.2 \%)$, standardization $(6.7 \%)>$ cold storage $(6.0 \%)>$ wastewater treatment (6.3\%), with an SEC of $0.267 \mathrm{MJ} / \mathrm{kg}$ of raw milk processed (RMP). The energy use was mainly due to the thermal energy (natural gas) used for CIP and pasteurization operations and the electrical energy used mainly for milk packaging and homogenization. Nonprocess electricity and thermal energy used throughout the plant were accounted for by the nonprocess factors discussed previously.

Table 2 shows a comparison of the energy used in each unit operation of the FMPM to that of the alternative processes. To simplify the comparisons in energy use among the plants, an attempt was made to keep most of the unit operations from plant to plant the same to emphasize the effect of the alternative methodology on total energy use and SEC. For example, each plant was assumed to have the same energy use associated with the raw milk section, which includes milk reception and storage in silos. The standardization and homogenization processes were also assumed to be the same for each of the alternative processes, except for the MF process with a VCR of 20 for which partial homogenization was assumed. Milk packaging was assumed the same for each process with the exception of the UHT process that assumed use of aseptic packaging. Cream packaging was also the same for each process.

The total SEC of the base FMPM (Figure 1) was $0.267 \mathrm{MJ} / \mathrm{kg}$ of RMP with SEC from electrical use of $0.14 \mathrm{MJ} / \mathrm{kg}$ of RMP and that from natural gas use of $0.13 \mathrm{MJ} / \mathrm{kg}$ of RMP (Table 2). In comparison, SEC of the simulated UHT process (Figure 2) was within 1\% of SEC for the FMPM but SEC due to natural gas use increased to $0.17 \mathrm{MJ} / \mathrm{kg}$ because of the higher temperature used to sterilize the milk. The aseptic packaging consumed only $7.8 \%$ of total energy, whereas in the FMPM, packaging consumed $23.9 \%$ of the total plant energy due to the use of electrical energy used to blowmold the packaging. Ultrahigh temperature milk does not require refrigeration, which is also another factor reducing SEC relative to the FMPM. The SEC due to electrical use was $0.10 \mathrm{MJ} / \mathrm{kg}$ of RMP.

High-temperature, short-time pasteurization is not a part of the raw milk ESL process (Figure 3) described in Gésan-Guiziou (2010), but the skim milk stream is heated to $55^{\circ} \mathrm{C}$ by regenerative heating to facilitate MF. The total energy use for the raw milk ESL process is about $10 \%$ higher than that of FMPM (Table 2) because of the additional electrical energy requirements of $\mathrm{MF}$, even though there is a small decrease in thermal energy use because milk was not heated to $72^{\circ} \mathrm{C}$. There is also a small increase in energy because the entire cream stream was pasteurized, whereas for the FMPM or UHT scenarios, about $72 \%$ of the cream was mixed with the skim milk to manufacture the whole milk product. The SEC due to natural gas use was 0.14 $\mathrm{MJ} / \mathrm{kg}$ of RMP for this process. The energy expended for CIP operations and treatment of wastewater also increased, which was attributed to cleaning of the MF units and the increase in the water volume required for cleaning. The SEC due to electricity use was $0.16 \mathrm{MJ} /$ 
$\mathrm{kg}$ of RMP. The original process discussed by GésanGuiziou (2010) packaged milk aseptically, not in the high-density polyethylene gallon jugs assumed for this process. Aseptic packaging would lower SEC due to electricity but cold storage would still be required. The total SEC was $0.293 \mathrm{MJ} / \mathrm{kg}$ of RMP compared with the value of $0.267 \mathrm{MJ} / \mathrm{kg}$ of RMP for FMPM.

The energy use for crossflow MF/HTST with a VCR of 200 (Figure 4) is also presented in Table 2. The total SEC was $0.329 \mathrm{MJ} / \mathrm{kg}$ of RMP. The SEC for electrical use was $0.16 \mathrm{MJ} / \mathrm{kg}$ of RMP, similar to that of the ESL raw milk process. The SEC from natural gas use was $0.17 \mathrm{MJ} / \mathrm{kg}$ of RMP compared with the value of 0.13 for FMPM because of the increased energy demands of the CIP operation. Also, the standardized permeate stream from MF entered the second preheat regeneration section at a lower temperature than that for the FMPM, resulting in a lower percentage regeneration of 93\% compared with $94 \%$ for the FMPM.

The process proposed by GEA Inc. (2013; Figure 5) used a single MF (VCR = 20) unit with HTST pasteurization at $74^{\circ} \mathrm{C}$ and partial homogenization to blend the retentate and cream streams, which were then treated at $100^{\circ} \mathrm{C}$ for $6 \mathrm{~s}$ before being added back to the permeate. The reported energy for MF of 3,752,400 MJ includes 1,598,020 MJ of energy from electricity and 2,154,380 MJ from natural gas used to generate steam for the retentate-cream pasteurization. The remaining cream was pasteurized separately. Because of the use of partial homogenization, SEC for electricity was 0.13 $\mathrm{MJ} / \mathrm{kg}$ of RMP, less than that of the FMPM (0.14) and the MF/HTST (VCR $=200)$ process (0.16). However, SEC for natural gas use increased to $0.19 \mathrm{MJ} / \mathrm{kg}$ of RMP, reflecting the increased use of natural gas during MF to heat the retentate and the cream stream. The total SEC was $0.328 \mathrm{MJ} / \mathrm{kg}$ of RMP similar to that of the MF/HTST $(\mathrm{VCR}=200)$ process.

The energy use for the PEF process (Figure 6) is also reported in Table 2. The PEF process flow sheet is similar to that of the MF process without HTST pasteurization (Figure 3). The total energy use for PEF alone was $31,455,520 \mathrm{MJ}$, which accounts for $51.7 \%$ of the total energy use of the process; SEC was $0.538 \mathrm{MJ} /$ $\mathrm{kg}$ of RMP. The SEC from natural gas use of 0.10 MJ/ $\mathrm{kg}$ of RMP was lowest for this process, with the decrease attributed to more efficient energy recovery due to the higher exit temperature from PEF entering the regenerator compared with that of the MF process of Figure 3. Toepfl et al. (2006) indicated that for cases such as this, in which the PEF is used for microbial decontamination, the input of electrical energy might be minimized to that of thermal pasteurization, which would be equivalent to approximately 4,867,250 MJ or $42.8 \mathrm{MJ} / \mathrm{kg}$ of RMP using the value from the FMPM, and then use synergetic heat effects, assuming $95 \%$ of heat recovery.

\section{GHG Emissions of Simulated Plants}

The energy data reported in Table 2 were used to calculate $\mathrm{GHG}$ emissions ( $\mathrm{kg}$ of $\mathrm{CO}_{2} \mathrm{e}$ ) for each unit operation of the base FMPM plant and for the alternative processes as shown in Table 3. Emissions in terms of grams of $\mathrm{CO}_{2} \mathrm{e}$ per kilogram of RMP (i.e., the carbon footprint of the process) are reported as well as the GHG emissions from use of electrical and natural gas energy. The GHG emissions ranged from a low of $31.4 \mathrm{~g}$ of $\mathrm{CO}_{2} \mathrm{e} / \mathrm{kg}$ of RMP for the UHT process to $99 \mathrm{~g}$ of $\mathrm{CO}_{2} \mathrm{e} / \mathrm{kg}$ of RMP for the PEF process. For all processes, GHG emissions arising from natural gas use were low compared with those arising from electrical use. Most cold storage facilities in dairy plants and distribution centers are ammonia-based (Brush et al., 2011) so GHG emissions from leakage of refrigerant are not considered here.

Waste water from fluid milk plants may be treated by the local municipality or in an onsite waste water facility. We assumed an aerobic onsite facility in the simulation, as described previously (Tomasula et al., 2013), in which biomass, $\mathrm{CO}_{2}$, and water were produced by breakdown of the milk components by bacteria. The generated $\mathrm{CO}_{2}$ was not added to the GHG emissions of Table 3. According to the IPCC (2006), $\mathrm{CO}_{2}$ generated from an aerobic process is biogenic because it results from the decomposition of biological material and is not derived from fossil fuels. If the amount of $\mathrm{CO}_{2}$ generated by wastewater treatment is taken into account, the following values for $\mathrm{CO}_{2} \mathrm{e}$ would be added to those in Table 3 for wastewater treatment: FMPM: 66,264 $\mathrm{kg} / \mathrm{yr}$; UHT: 73,329 kg/yr; crossflow MF, no HTST: 71,399 kg/yr; crossflow MF/HTST $(\mathrm{VCR}=200): 86$, $571 \mathrm{~kg} / \mathrm{yr}$; crossflow MF/HTST (VCR = 20): 85,569 $\mathrm{kg} / \mathrm{yr}$; and PEF: 66,267 kg/yr.

\section{Capital, Operating, and Unit Production Costs}

Energy reduction measures are followed by reductions in GHG emissions but not necessarily by reductions in cost. The economic evaluation report issued by the simulator software provides a summary of the capital costs of the equipment, the operating costs, and unit operating costs for conducting an economic analysis of the process. The capital costs for the FMPM and the alternative processing plants are given in Table 4. The costs for the buildings and auxiliary costs relate only to the building associated with the process and not to other buildings on the site. All other equipment costs were determined as previously described (Tomasula et 
Table 3. Greenhouse gas emissions ( $\mathrm{kg}$ of $\mathrm{CO}_{2} \mathrm{e} ; \%$ in parentheses) associated with electricity and natural gas use to process $113,600,000 \mathrm{~L} / \mathrm{yr}$ raw milk using the fluid milk process model (FMPM), UHT processing, crossflow microfiltration (MF) with no pasteurization and a volume concentration ratio (VCR) of 200, MF/HTST with a VCR of 200, MF/HTST with a VCR of 20 , or pulsed electric field processing (PEF)

\begin{tabular}{|c|c|c|c|c|c|c|}
\hline Section & $\begin{array}{l}\text { FMPM with } \\
\text { HTST at } 77^{\circ} \mathrm{C}\end{array}$ & $\begin{array}{l}\text { UHT } \\
\text { process }\end{array}$ & $\begin{array}{c}\text { Crossflow MF, } \\
\text { no HTST } \\
(\text { VCR }=200)\end{array}$ & $\begin{array}{c}\text { Crossflow } \\
\mathrm{MF} / \mathrm{HTST} \\
\text { at } 74^{\circ} \mathrm{C} \\
(\mathrm{VCR}=200)\end{array}$ & $\begin{array}{c}\text { Crossflow }^{1} \\
\text { MF } / \text { HTST }^{\circ} \\
\text { at } 74^{\circ} \mathrm{C} \\
(\mathrm{VCR}=20)\end{array}$ & $\mathrm{PEF}$ \\
\hline Raw milk & $\begin{array}{r}52,393 \\
(1.2)\end{array}$ & $\begin{array}{r}52,393 \\
(1.5)\end{array}$ & $\begin{array}{r}52,393 \\
(1.1)\end{array}$ & $\begin{array}{r}52,393 \\
(1.1)\end{array}$ & $\begin{array}{r}52,393 \\
(1.1)\end{array}$ & $\begin{array}{r}52,393 \\
(0.5)\end{array}$ \\
\hline Microfiltration & - & - & $\begin{array}{r}353,299 \\
(7.5)\end{array}$ & $\begin{array}{r}354,346 \\
(7.1)\end{array}$ & $\begin{array}{r}473,238 \\
(10.3)\end{array}$ & - \\
\hline Pulsed electric fields & - & - & - & - & - & $\begin{array}{c}6,633,195 \\
(59.0)\end{array}$ \\
\hline Pasteurization & $\begin{array}{r}505,557 \\
(11.8)\end{array}$ & $\begin{array}{r}1,192,145 \\
(33.4)\end{array}$ & $\begin{array}{l}483,315 \\
(10.3)\end{array}$ & $\begin{array}{l}515,476 \\
(10.4)\end{array}$ & $\begin{array}{r}543,192 \\
(11.8)\end{array}$ & $\begin{array}{r}830,436 \\
(7.4)\end{array}$ \\
\hline Homogenization & $\begin{array}{r}588,166 \\
(13.8)\end{array}$ & $\begin{array}{r}590,591 \\
(16.6)\end{array}$ & $\begin{array}{r}583,619 \\
(12.4)\end{array}$ & $\begin{array}{r}585,007 \\
(11.8)\end{array}$ & $\begin{array}{r}76,661 \\
(1.7)\end{array}$ & $\begin{array}{r}589,504 \\
(5.2)\end{array}$ \\
\hline Standardization & $\begin{array}{r}407,464 \\
(9.5)\end{array}$ & $\begin{array}{r}407,468 \\
(11.4)\end{array}$ & $\begin{array}{r}406,976 \\
(8.7)\end{array}$ & $\begin{array}{r}407,464 \\
(8.2)\end{array}$ & $\begin{array}{r}406,927 \\
(8.9)\end{array}$ & $\begin{array}{r}407,345 \\
(3.6)\end{array}$ \\
\hline Milk packaging & $\begin{array}{r}1,521,845 \\
(35.7)\end{array}$ & $\begin{array}{c}477,522 \\
(13.4)\end{array}$ & $\begin{array}{r}1,514,219 \\
(32.2)\end{array}$ & $\begin{array}{c}1,514,226 \\
(30.55)\end{array}$ & $\begin{array}{c}1,521,827 \\
(33.2)\end{array}$ & $\begin{array}{r}1,521,831 \\
(13.5)\end{array}$ \\
\hline Cream pasteurization & $\begin{array}{r}40,530 \\
(0.9)\end{array}$ & $\begin{array}{r}47,370 \\
(1.3)\end{array}$ & $\begin{array}{r}48,133 \\
(1.0)\end{array}$ & $\begin{array}{r}40,735 \\
(0.8)\end{array}$ & $\begin{array}{r}33,350 \\
(0.7)\end{array}$ & $\begin{array}{r}47,290 \\
(0.4)\end{array}$ \\
\hline Cream packaging & $\begin{array}{r}42,050 \\
(1.0)\end{array}$ & $\begin{array}{r}41,944 \\
(1.2)\end{array}$ & $\begin{array}{r}43,003 \\
(0.9)\end{array}$ & $\begin{array}{r}42,996 \\
(0.9)\end{array}$ & $\begin{array}{r}42,071 \\
(0.9)\end{array}$ & $\begin{array}{r}42,067 \\
(0.4)\end{array}$ \\
\hline Cold storage & $\begin{array}{r}384,859 \\
(9.0)\end{array}$ & - & $\begin{array}{r}384,859 \\
(8.2)\end{array}$ & $\begin{array}{r}384,859 \\
(7.7)\end{array}$ & $\begin{array}{r}384,859 \\
(8.4)\end{array}$ & $\begin{array}{r}384,859 \\
(3.4)\end{array}$ \\
\hline Cleaning-in-place & $\begin{array}{c}573,991 \\
(13.4)\end{array}$ & $\begin{array}{r}588,494 \\
(16.5)\end{array}$ & $\begin{array}{r}662,779 \\
(14.1)\end{array}$ & $\begin{array}{r}873,910 \\
(17.6)\end{array}$ & $\begin{array}{r}859,501 \\
(18.7)\end{array}$ & $\begin{array}{r}573,991 \\
(5.1)\end{array}$ \\
\hline Wastewater treatment & $\begin{array}{r}151,205 \\
(3.5)\end{array}$ & $\begin{array}{r}167,053 \\
(4.7)\end{array}$ & $\begin{array}{r}162,669 \\
(3.5)\end{array}$ & $\begin{array}{r}196,917 \\
(4.0)\end{array}$ & $\begin{array}{r}194,596 \\
(4.2)\end{array}$ & $\begin{array}{r}151,206 \\
(1.3)\end{array}$ \\
\hline Total GHG emissions & $4,268,060$ & $3,564,979$ & $4,695,264$ & $4,968,328$ & $4,588,614$ & $11,234,118$ \\
\hline $\mathrm{GHG}, \mathrm{g} / \mathrm{kg}$ of $\mathrm{RMP}^{2}$ & 37.6 & 31.4 & 41.4 & 43.8 & 40.5 & 99.1 \\
\hline GHG, $\mathrm{g} / \mathrm{kg}$ of RMP, natural gas & 7.9 & 10.9 & 8.7 & 10.9 & 12.2 & 6.1 \\
\hline $\mathrm{GHG}, \mathrm{g} / \mathrm{kg}$ of RMP, electricity & 29.7 & 20.6 & 32.7 & 32.9 & 28.2 & 93.0 \\
\hline
\end{tabular}

artial homogenization.

${ }^{2}$ Raw milk processed. 
Table 4. Capital costs $(\$ \times 1,000)$ by section for the equipment used to process $113,600,000 \mathrm{~L} / \mathrm{yr}$ milk in the fluid milk process model (FMPM), UHT processing, crossflow microfiltration (MF) with no pasteurization and with a volume concentration ratio (VCR) of 200, MF/HTST with a VCR of 200, MF/HTST with a VCR of 20, and pulsed electric field processing (PEF)

\begin{tabular}{|c|c|c|c|c|c|c|}
\hline Section & $\begin{array}{l}\text { FMPM with } \\
\text { HTST at } 77^{\circ} \mathrm{C}\end{array}$ & $\begin{array}{c}\text { UHT } \\
\text { process }\end{array}$ & $\begin{array}{c}\text { Crossflow } \\
\text { MF, no HTST } \\
(\text { VCR }=200)\end{array}$ & $\begin{array}{c}\text { Crossflow } \\
\mathrm{MF} / \mathrm{HTST} \\
\text { at } 74^{\circ} \mathrm{C} \\
(\mathrm{VCR}=200)\end{array}$ & $\begin{array}{c}\text { Crossflow }^{1} \\
\mathrm{MF} / \mathrm{HTST} \\
\text { at } 74^{\circ} \mathrm{C} \\
(\mathrm{VCR}=20)\end{array}$ & PEF \\
\hline Microfiltration & - & - & 676 & 678 & 598 & - \\
\hline Pulsed electric field & - & - & - & - & - & 7,653 \\
\hline Pasteurization & 396 & 4,929 & 236 & 394 & 396 & 109 \\
\hline Milk packaging & 7,373 & 10,952 & 7,364 & 7,364 & 7,373 & 7,373 \\
\hline Cream pasteurization & 53 & 53 & 54 & 53 & 53 & 54 \\
\hline Cream packaging & 1,777 & 1,773 & 1,554 & 1,554 & 1,541 & 1,541 \\
\hline Cold storage & 543 & 543 & 543 & 543 & 543 & 543 \\
\hline Cleaning-in-place & 1,971 & 1,971 & 1,971 & 1,971 & 1,971 & 1,971 \\
\hline Wastewater treatment & 1,985 & 1,992 & 1,989 & 2,002 & 2,000 & 1,985 \\
\hline Building and auxiliary costs & 10,000 & 10,000 & 10,000 & 10,000 & 10,000 & 10,000 \\
\hline
\end{tabular}

${ }^{1}$ Partial homogenization.

al. 2013). Capital costs were lowest for the crossflow MF/HTST process with VCR of 20 but were highest for the UHT process, which had the lowest energy use and GHG emissions, closely followed by the PEF process, which had the highest energy use and GHG emissions.

The annual operating costs for the FMPM and the alternative processing plants are shown in Table 5, which provides information on the costs of the raw materials, utilities, labor, and the waste treatment costs at the plants. Capital depreciation calculated using the straight-line method (Peters et al., 2003) is also listed. As in the previous study (Tomasula et al., 2013), other assumed facility-dependent costs included plant maintenance at $3 \%$ of capital costs; insurance at $0.8 \%$ of capital costs, and factory expenses at $0.75 \%$ of capital costs. Unit production costs are the difference between the operating costs and the co-products credit for cream divided by the number of filled entities. Note that the number of filled entities in Table 5 for UHT milk is reported in units of liters because UHT milk is usually packaged in 1-L bricks, not in gallon containers. The raw material costs are the largest contributor to the total production costs, with the price of milk contributing $90 \%$ of the total production costs. Unit production costs for the FMPM and the MF/HTST process with VCR of 20 were found to be the same at $\$ 0.507 / \mathrm{L}$. However, the unit production costs of the UHT process were $\$ 0.093 / \mathrm{L}$ (\$0.35/gal) greater than those of the FMPM; those of the PEF process were $\$ 0.016 / \mathrm{L}(\$ 0.06 /$ gal $)$ greater than those of the FMPM; and those of the MF/HTST process with a VCR of 200 were $\$ 0.003 / \mathrm{L}(\$ 0.01 /$ gal) greater than those of the FMPM, which was within the range reported by Skrzypek and Burger (2010) in a compari-

Table 5. Summary of capital, operating, and production costs $(\$ \times 1,000)$ used to process $113,600,000 \mathrm{~L} / \mathrm{yr}$ whole milk using the fluid milk process model (FMPM), UHT processing, crossflow microfiltration (MF) with no pasteurization and with a volume concentration ratio (VCR) of 200, MF/HTST with a VCR of 200, MF/HTST with a VCR of 20, and pulsed electric field processing (PEF)

\begin{tabular}{|c|c|c|c|c|c|c|}
\hline Item & $\begin{array}{c}\text { FMPM, } \\
\text { HTST }\end{array}$ & $\begin{array}{c}\text { UHT } \\
\text { process }\end{array}$ & $\begin{array}{c}\text { Crossflow MF, } \\
\text { no HTST } \\
(\text { VCR }=200)\end{array}$ & $\begin{array}{c}\text { Crossflow } \\
\text { MF/HTST } \\
(\text { VCR }=200)\end{array}$ & $\begin{array}{c}\text { Crossflow } \\
\text { MF/HTST } \\
(\mathrm{VCR}=20)\end{array}$ & $\begin{array}{c}\text { PEF } \\
\text { process }\end{array}$ \\
\hline Filled entities ${ }^{1}$ & $29,161,110$ & $110,392,088$ & $29,014,987$ & $29,015,116$ & $29,160,772$ & $29,160,827$ \\
\hline Operating costs & 60,347 & 70,565 & 60,463 & 60,602 & 60,435 & 62,091 \\
\hline Utilities & 429 & 470 & 457 & 478 & 446 & 1,123 \\
\hline Waste treatment & 12 & 13 & 13 & 16 & 16 & 12 \\
\hline Other facility costs & 1,297 & 1,666 & 1,313 & 1,317 & 1,272 & 1,625 \\
\hline Capital depreciation & 2,850 & 3,662 & 2,886 & 2,895 & 2,795 & 3,571 \\
\hline Co-products credit & 4,387 & 4,376 & 4,487 & 4,486 & 4,389 & 4,389 \\
\hline Unit production costs, $\$ / \mathrm{MP}$ entity ${ }^{1}$ & 1.92 & 0.60 & 1.93 & 1.93 & 1.92 & 1.98 \\
\hline
\end{tabular}

${ }^{1} \mathrm{MP}$ entity $=1$ gallon of whole milk packaged $=3.785 \mathrm{~L}$ of whole milk packaged for all processes except UHT, where MP entity $=1 \mathrm{~L}$ of whole milk packaged. 
son of a similar commercial milk MF/HTST process with an FMPM.

\section{Water Use}

The FMPM and other models presented in this study predict the amount of water used in each unit operation. However, detailed information on plant or process water use is not available in the literature or from processors for the FMPM or UHT process. The earlier study (Tomasula et al., 2013) reported that information on water use for entire fluid milk processing plants was available and ranged from $1.02 \mathrm{~L}$ of water/L of milk processed to $3 \mathrm{~L}$ of water/L of milk processed. For the FMPM, it was reported that $0.3 \mathrm{~L}$ of water was used for CIP and case washing per L of milk processed. Similar results were obtained in this study for the various processes and are reported in parentheses ( $\mathrm{L}$ of water/L of milk processed): FMPM (0.245), UHT process (0.273), crossflow MF, no HTST (0.271), crossflow MF/HTST,VCR of 200 (0.333), crossflow MF/HTST, VCR of 20 (0.329), and PEF process (0.245).

\section{Integrated Simulation Models}

Decreases in energy use, GHG emissions, and water use for the fluid milk process will be achieved through evaluations of the impact of farm and off-farm processes involved in the production of a gallon or liter of milk (Tomasula and Nutter, 2011). This may be done most efficiently through the use of software tools for farm management simulation, such as that described in Rotz et al. (2012), and process simulation, such as that described in Tomasula et al. (2013). Software tools will also allow integration of the farm with the processing plant to improve the sustainability of the fluid milk supply by shared decreases in energy, water use, and GHG emissions, which is of concern in the context of food security and food nutrition. Integration of indicators such as the Nutrient Density to Climate Impact Index (Smedman et al. 2010), which relates the nutrient profile of a food to GHG emissions, and information on the bioavailability of foods would also become part of simulation schemes to monitor the linkage between farm or off-farm processes and nutrition. Computer simulation will help lay the foundation for designing dairy plants of the future by integrating new technologies into the existing dairy supply chain to lower energy use, reduce or eliminate water use, eliminate waste, and ensure food security.

\section{CONCLUSIONS}

The simulations demonstrate that FMPM is the most energy efficient process with both the lowest
SEC and lowest unit production costs of all processes examined. However, for the MF/HTST processes, the shelf life of milk is longer relative to the FMPM. The increase in shelf life of the MF/HTST processes may offset the increase in GHG emissions relative to the FMPM. Although UHT milk had the highest unit production costs, it had the advantage of the lowest GHG emissions. The PEF process is still under development and costs will likely decrease with further advances in the technology. This process also offers the potential of an extended shelf life relative to the FMPM. These new models, along with the original version of the fluid milk process simulator (Tomasula et al., 2013) and a user manual, are available for download (http://ars. usda.gov/naa/errc/fluidmilkprocessmodels). The free evaluation version of SuperProDesigner can be downloaded from www.intelligen.com to view and examine the models.

\section{REFERENCES}

ASHRAE (American Society of Heating, Refrigerating and Air-Conditioning Engineers). 2007. ASHRAE 2007 Handbook: Heating, ventilating, and air-conditioning applications. 1-P ed. Knovel, New York, NY

Brush, A., E. Masanet, and E. Worrell. 2011. Energy efficiency improvement and cost saving opportunities for the dairy processing industry. An ENERGY STAR ${ }^{\circledR}$ guide for energy and plant managers. Lawrence Berkeley National Laboratory, Berkeley, CA. Accessed Jan. 21, 2014. http://eetd.lbl.gov/sites/all/files/lbnl-5303e. pdf.

Burton, J. 1988. Ultra-High Temperature Processing of Milk and Milk Products. Elsevier Applied Science, London, UK.

Datta, N., A. J. Elliott, M. L. Perkins, and H. C. Deeth. 2002. Ultrahigh-temperature (UHT) treatment of milk: Comparison of direct and indirect modes of heating. Aust. J. Dairy Technol. 57:211227.

Deru, M. and P. Torcellini. 2007. Source energy and emission factors for energy use in buildings. Technical Report, NREL/TP550-38617. Revised June 2007. National Renewable Energy Laboratory (NREL), Golden, CO.

Doty, S., and W. C. Turner. 2009. Energy Management Handbook. 7th ed. The Fairmount Press, Lilburn, GA.

Elwell, M. W., and D. M. Barbano. 2006. Use of microfiltration to improve fluid milk quality. J. Dairy Sci. 89(E. Suppl.):E10-E30.

FDA (US Food and Drug Administration). 2011. Grade "A", Pasteurized Milk Ordinance, 2007 revision. US Department of Health and Human Services Public Health Service. Accessed Sep. 12, 2013. http://www.fda.gov/downloads/Food/FoodSafety/ProductSpecificInformation/MilkSafety/NationalConferenceonInterstate MilkShipmentsNCIMSModelDocuments/UCM291757.pdf.

GEA Inc. 2013. Process concepts for the production of ESL milk. GEA TDS GmbH, Sarstedt, Germany. Accessed Sep. 15, 2013. http:// www.gea-tds.com/tds/cmsresources.nsf/filenames/451eTDS_ESL. pdf/\$file/451eTDS_ESL.pdf.

Gésan-Guiziou, G. 2010. Removal of bacteria, spores and somatic cells from milk by centrifugation and microfiltration techniques. Pages 349-372 in Improving the Safety and Quality of Milk: Milk Production and Processing. M. W. Griffiths, ed. Woodhead Publishing, Cambridge, MA.

Goff, H. D., and M. W. Griffiths. 2006. Major advances in fresh milk and milk products: Fluid milk products and frozen desserts. J. Dairy Sci. 89:1163-1173.

Hoffman, W., C. Kiesner, I. Clawin-Radecker, D. Martin, K. Einhoff, P. C. Lorenzen, H. Meisel, P. Hammer, G. Suhren, and P. Teufel. 
2006. Processing of extended shelf-life milk using microfiltration. Int. J. Dairy Technol. 59:229-235.

IPCC (Intergovernmental Panel on Climate Change). 2006. Waste. Chapter 6 in Guidelines for National Greenhouse Gas Inventories. Vol. 5. M. R. J. Doorn, S. Towprayoon, S. M. M. Vieira, W. Irving, C. Palmer, R. Pipatti, and C. Wang, ed. Accessed Jan. 10, 2014 http://www.ipcc-nggip.iges.or.jp/public/2006gl/pdf/5_Volume5/ V5_6_Ch6_Wastewater.pdf.

Mañas, P., and R. Pagán. 2005. Microbial inactivation by new technologies for food preservation. J. Appl. Microbiol. 98:1387-1399.

NRCan (Natural Resources Canada). 2001. Energy Performance Indicator Report: Fluid Milk Plants. NRCan, Ottawa, ON, Canada.

Peters, M. S., K. D. Timmerhaus, and R. E. West. 2003. Plant Design and Economics for Chemical Engineers. 5th ed. McGraw-Hill, New York, NY.

Ranieri, M. L., J. R. Huck, M. Sonnen, D. M. Barbano, and K. J. Boor. 2009. High temperature, short time pasteurization temperatures inversely affect bacterial numbers during refrigerated storage of pasteurized fluid milk. J. Dairy Sci. 92:4823-4832.

Rotz, C. A., M. S. Corson, D. S. Chianese, F. Montes, S. D. Hafner, and U. Coiner. 2012. The Integrated Farm System Model. Reference Manual. Version 3.6. USDA Agricultural Research Service, University Park, PA. Accessed Sep. 1, 2013. http://www.ars.usda. gov/SP2UserFiles/Place/19020000/ifsmreference.pdf.

Rysstad, G., and J. Kolstad. 2006. Extended shelf life milk-Advances in technology. Int. J. Dairy Technol. 59:85-96.

Saboya, L. V., and J.-L. Maubois. 2000. Current developments of microfiltration technology in the dairy industry. Lait 80:541-553.

Sampedro, F., A. McAloon, W. Yee, X. Fan, H. Q. Zhang, and D. J. Geveke. 2013. Cost analysis of commercial pasteurization of orange juice by pulsed electric fields. Innov. Food Sci. Emerg. Technol. $17: 72-78$.

Skrzypek, M., and M. Burger. 2010. ISOFLUX ceramic membranesPractical experiences in dairy industry. Desalination 250:10951100.
Smedman, A., H. Lindmark-Mansson, A. Drewnowski, and A.-K. Modin Edman. 2010. Nutrient density of beverages in relation to climate impact. Food Nutr. Res. 54:5170-5178.

Sobrino-Lopez, A., and O. Martin-Belloso. 2010. Review: Potential of high-intensity pulsed electric field technology for milk processing. Food Eng. Rev. 2:17-27.

Thoma, G., J. Popp, D. Nutter, D. Shonnard, R. Ulrich, M. Matlock, D. S. Kim, Z. Neidermann, N. Kemper, C. East, and F. Adom. 2013. Greenhouse gas emissions from milk production and consumption in the United States: A cradle-to-grave life cycle assessment circa 2008. Int. Dairy J. 31:S3-S14.

Toepfl, S., A. Mathys, V. Heinz, and D. Knorr. 2006. Review: Potential of high hydrostatic pressure and pulsed electric fields for energy efficient and environmentally friendly food processing. Food Rev. Int. 22:405-423.

Tomasula, P. M., S. Mukhopadhyay, N. Datta, A. C. S. Porto-Fett, J. E. Call, J. B. Luchansky, J. Renye, and M. H. Tunick. 2011. Pilotscale crossflow-microfiltration and pasteurization to remove spores of Bacillus anthracis (Sterne) from milk. J. Dairy Sci. 94:42774291. http://dx.doi.org/10.3168/jds.2010-3879.

Tomasula, P. M., and D. W. Nutter. 2011. Mitigation of greenhouse gas emissions in the production of fluid milk. Adv. Food Nutr. Res. 62:41-88

Tomasula, P. M., W. C. F. Yee, A. J. McAloon, D. W. Nutter, and L. M. Bonnaillie. 2013. Computer simulation of energy use, greenhouse gas emissions, and process economics of the fluid milk process. J. Dairy Sci. 96:3350-3368.

$\mathrm{Xu}, \mathrm{T}$., and J. Flapper. 2009. Energy use and implications for efficiency strategies in global fluid-milk processing industry. Energy Policy 37:5334-5341. 